Article

\title{
Biofouling Growth in Cold Estuarine Waters and Evaluation of Some Chitosan and Copper Anti-Fouling Paints
}

\section{Émilien Pelletier *, Claudie Bonnet and Karine Lemarchand}

Institut des Sciences de la Mer de Rimouski, Université du Québec à Rimouski, 310 Allée des Ursulines, C.P.3300. Rimouski, QC, G5L 3A1, Canada; E-Mails: claudie.bonnet@nrc-cnrc.gc.ca (C.B.); Karine_lemarchand@uqar.qc.ca (K.L.)

* Author to whom correspondence should be addressed; E-Mail: emilien_pelletier@uqar.qc.ca; Tel. +01-418-723-1986 ext. 1764; Fax: +01-418-724-1842

Received: 20 May 2009; in revised form: 9 July 2009 / Accepted: 10 July 2009 /

Published: 14 July 2009

\begin{abstract}
Ecological concerns about antifouling paints containing non-green tin and copper compounds have highlighted the need for environmentally friendly alternatives. We report here a field test conducted in estuarine waters over two months designed to evaluate the efficiency of a number of active natural and man-made chemical ingredients added into a silicon-polyurethane marine pa int. Early steps of biofouling in cold seawater of th e St. Lawrence Estuary (Canada) were observed. Analyses, including dry biom ass, flow cytometry and spectrofluorim etry, dem onstrated a short-term antibacterial actio $\mathrm{n}$ of chitosan-based paints although no significant anti-algal action was observed. Cuprous oxide paints were efficient against bacteria and algae invasion in the first two w eeks, especially those with added organic biocides such as isothiazolone and copper pyrithione. However, the overall dry biomass and chlorophyll a content were similar for all chitosanand copper-based paints after 63 days. Microsc opic observations reveal ed variation in the highly diverse benthic diatom population including species Navicula, Melosira, Cocconeis, Nitshzcia, Fragilaria and Amphora. Results suggest no real long-term efficiency for tested antifouling paints and highlight a particular need for green an tifouling ingredients that are active under northern estuarine conditions.
\end{abstract}

Keywords: marine biofouling; copper antifouling paint; chitosan ; static field testing; microalgae 


\section{Introduction}

Being a source of environm ental and economical problems, the invasive bi ofouling process creates adverse effects on all immersed structures limiting their utilization and accelerating their corrosion. Of all the solutions proposed to prev ent biofouling, tributyltin (TBT) self-polishing copolym er paints were by far the $\mathrm{m}$ ost successful solution and were used on more than $70 \%$ of the world comm ercial fleet in mid-1990s [1]. Unfortunately, TBT was found to be the most toxic substance ever introduced in the $\mathrm{m}$ arine environ ment, with harmf ul effects to non-target organism $\mathrm{s}$ [2 ]. Tin-free alternative antifouling chemical agents for use in the aquatic environm ent have been a topic of increasing concern over the past years as stable degradation prod ucts could cause environm ental problem s by their increasing concentrations $[1,4]$. A number of na tural products were i nvestigated for their antifouling potential. Com pounds isolated from $\mathrm{m}$ arine organism $\mathrm{s}$ such as $\mathrm{b}$ acteria, algae, cnidaria, bryozoa, chordate an $d$ other sessile ben thic invertebrate s were tested again st biofouling [4,5,6]. A r ecent example is given by Tsoukatou et al. [7], where sponge $\mathrm{m}$ etabolites and their sy nthetic derivatives were tested in laboratory against fouling organisms.

Among organic polymers highly abundant in marine crustaceans, chitosan, obtained from the partial deacetylation of chitin, possesses a ntimicrobial prope rties agains $t$ a nu mber of organism s, including bacteria, fungi and algae [8,9]. Chitosan could be part of a green chem istry approach to fight biofouling as it com es mainly from seafood by-produc ts and its prepar ation requires a lim ited number of steps. Although a large num ber of laboratory test $\mathrm{s}$ and assays have been developed to assess the activity of organic and mineral compounds against fouling organisms [7,10,11] few practical field tests have been described [12], particularly in cold waters where the fouling process is slow.

The first aim of this work was to test the efficiency of finely ground (60 $\mathrm{m} \quad$ esh) chitosan incorporated as an antifouling additive into a polyurethane marine paint lacking any other biocide. The second objective of this work was to develop a practical in situ test for estuarine waters to des cribe early steps of biofouling on painted $\mathrm{m}$ etal plates and quantify its progress over a two-m onth static exposure. $\mathrm{N}$ ever assessed before, the effectiveness of chitosan granular polym er as an additive to marine paint is reported and compared to three commercially available antifouling marine paints.

\section{Results and Discussion}

The early microbial biofouling com munity has neve $r$ been describ ed in the St. Lawrence Estu ary (Eastern Canada) where cold wate rs persist year-round. The tem poral sequence of bacterial-algal communities in the slime film developing on a surface immersed in the Atlantic seawater was detailed in early 1950 s in a bo ok publish ed by the Woods Hole Oceanographic Inst itute where bacterial concentrations were rep orted to reach $10^{6}$ organisms $\mathrm{cm}^{-2}$ within two days [21]. The se values are far higher than the counts $\left(\begin{array}{ll}4 & 4 \\ - & -10^{5} \text { bacteria } \mathrm{cm}^{-2}\end{array}\right)$ obtained in the present study after 14 days. Meteorological conditions prevailing in this northern estuary, and especially its low water temperature, are probably responsible for the slow bacterial colonization. Even under these low growth rate conditions, a thin sticky biological layer was observed on every panel in the first three weeks. 


\subsection{Bacterial Counts}

Paint compositions and abbrevia tions are given in Table 1. CuO, Oma and $S N$ are copper-based paints, whereas $C 1$ and $C 2$ are chitosan-based paints.

Table 1. Industrial and chitosan paints used in the field test.

\begin{tabular}{lc}
\hline Industrial Name & Identification \\
\hline Cuprous oxide paint (Bottomkote ${ }^{\circledR} X X X$, Interlux, Ltd.) & $C u O$ \\
Isothiazolone. Sea-Nine ${ }^{\circledR} 211$ (Rohm \& Haas Company, Inc., Philadelphia, & \\
US), concentrated 5\% in copper paint & $S N$ \\
Copper pyrithione, Copper Omadine ${ }^{\mathrm{TM}}$ (Arch Chemicals, Inc., Norwalk, US), & \\
concentrated 5\% in copper paint & Oma \\
Silicon-polyurethan Easypoxy ${ }^{\mathrm{TM}}$ (Pettit Marine Paints, Inc., Rockaway, US) & Ep \\
\hline Chitosans * added in Easypoxy paint Ep & \\
\hline Chitosan $100 \%$ of deacylation, $480 \mathrm{KDa}$, concentrated 5\% $\left(\mathrm{w} \mathrm{v}^{-1}\right)$ & $C 1$ \\
Chitosan $100 \%$ of deacylation, $480 \mathrm{KDa}$, concentrated 20\% $\left(\mathrm{w} \mathrm{v}^{-1}\right)$ & $C 2$ \\
\hline
\end{tabular}

* All chitosans were pulverized to 60 mesh prior to use.

The relatively low bacterial count for all plates is probably due to the low temperature, as nutrients were abundant and typical of estuarine conditions. The bacterial abundance per $\mathrm{cm}^{2}$ increased by about four orders of magnitude within the first 14 days after immersion (Figure 1).

Figure 1. Concentration of bacteria $\mathrm{cm}^{-2}$ after 1, 4 and 14 days. CuO, Oma and $S N$ are copper-based paints, w hereas $C 1$ and $C 2$ are chitosan-based paints and $E p$ is the pain $\mathrm{t}$ without additive.

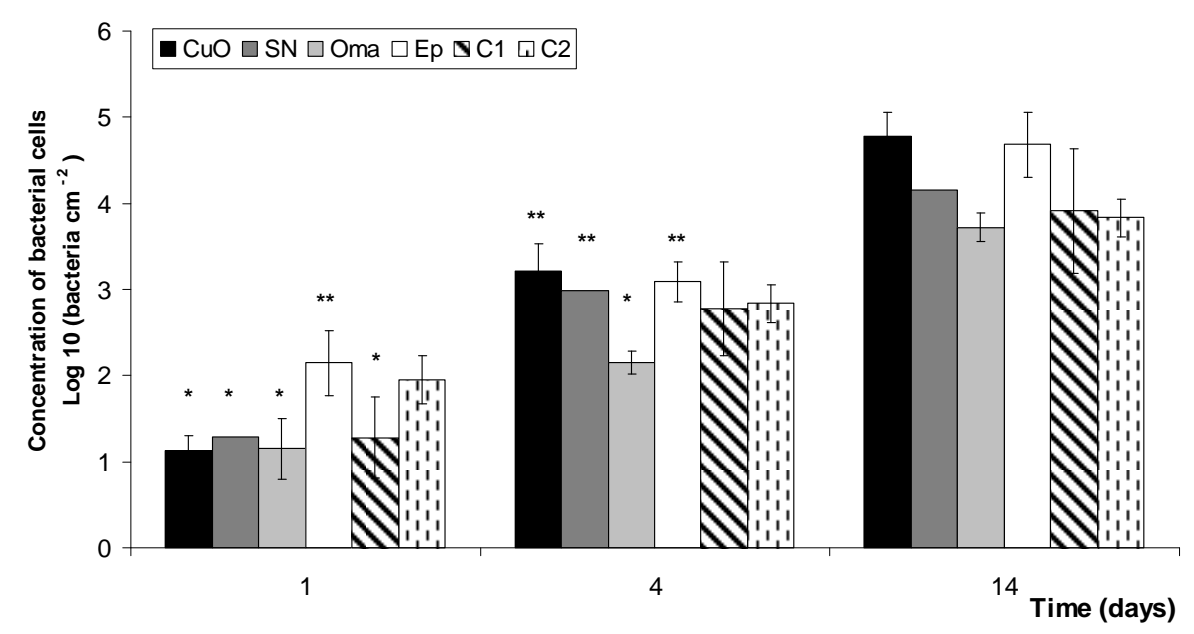

Standard deviation is shown $\mathrm{w}$ ith error bars. Colum ns with on e asterisk (*) present values no $t$ different to each other or to columns without asterisks, but are significantly different to values from columns with two asterisk $\mathrm{s}\left({ }^{* *}\right)$. Colu mns without asterisk are not significant ly different to each other for the same day. 
After the first $24 \mathrm{~h}$ of exposur e, the free-biocide paint, Ep, already presented a significantly higher concentration of surface bacteria than the an ti-fouling pain ts $\mathrm{C1}, \mathrm{CuO}, \mathrm{Oma}$ and $S N$. Data show a weaker bacterial attachment on the chitosan paint $C 1\left(5 \% \mathrm{w} \mathrm{v}^{-1}\right)$ compared to commercial antifouling paints. After 4 days, Oma presented a significan tly lower number of bac terial cells than $\mathrm{CuO}, \mathrm{Ep}$ and $S N$, but did not present significant differences with $C 1$ or $C 2$, suggesting an antim icrobial action of both chitosan formulated paints. After 14 days, the tendency of Oma and $C 2\left(20 \% \mathrm{w} \mathrm{v}^{-1}\right)$ panels to be less colonised by bacteria is still visible, but was not significantly different from others.

\subsection{Algae Counts and Chlorophyll A Content}

Concentrations of phytoplankton cells settled on painted panels in the first tw o weeks were relatively low, between 60 to 130 cells $\mathrm{cm}^{-1}$ (Figure 2). Significant diffe rences in the number of attached cells $\mathrm{cm}^{-2}$ between panels only appeared after 14 days. Panels Ep, C1 and C2 presented cell concentrations much higher than copper form ulated an tifouling pain ts. Copper paints with ad ditives ( $\mathrm{SN}$ and $\mathrm{Oma}$ ) seem less efficient than the free-additive copper paint $\mathrm{CuO}$ (Figure 2).

Figure 2. Concentration of phytoplanktonic cells $\mathrm{cm}^{-2}$ after 1, 4 and 14 days. Standard deviation is shown with error bars. Meaning of asterisks is as given in Figure 1.

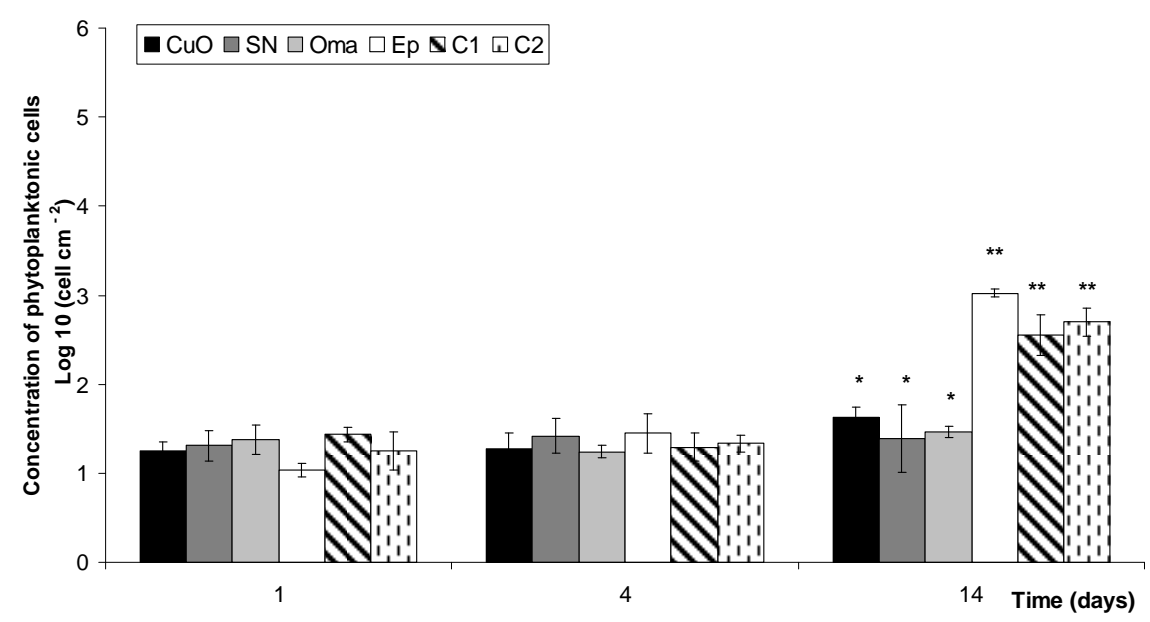

Chlorophyll $a(\mathrm{Chl}$ a) concentration s on the surface of te sted panels increased by four orders o $\mathrm{f}$ magnitude over the exposure peri od of 63 days (Figure 3). $\mathrm{C}$ hl $a$ results after 14 days also reveal the lack of anti-algal efficiency for polyurethane-silicone based paints ( $E p, C 1$ and $C 2$ ), as the number of cells $\mathrm{cm}^{-2}$ is over 10 times higher than copper paints . Although a com parable efficiency of $\mathrm{CuO}, \mathrm{SN}$, and Oma is observed on day 14, important changes are visible in the following two weeks as paints with additives ( $S N$ and $O m a$ ) are significantly more efficient at day 21 and day 28. However, the final sampling showed concentration s reaching $10{ }^{6} \mathrm{ng} \mathrm{cm}^{-2}$ for all panels without differences between paints. 
Figure 3. Chlorophyll $a$ in $\mathrm{ng} \mathrm{c} \mathrm{m}^{-2}$ after 1, 4, 14, 21, 28, 56 and $63 \mathrm{i}$ mmersion days. Standard deviation is shown $\mathrm{w}$ ith the e rror ba rs. Me aning of aste risks is as give $\mathrm{n}$ in Figure 1.

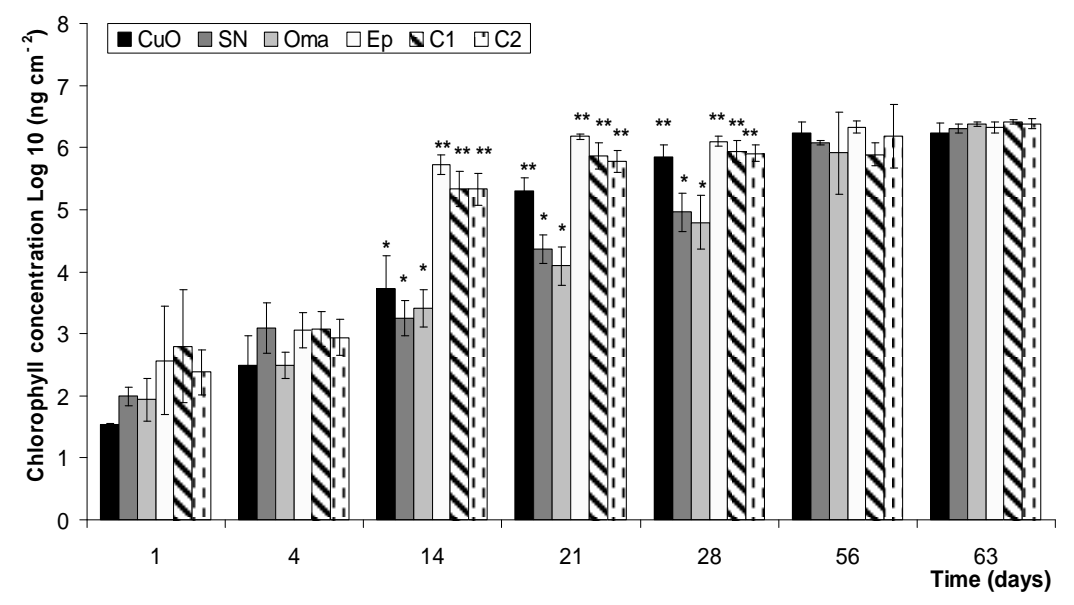

\subsection{Total Dry Biomass}

An increase of the dry fouled biom ass in time was undeniable (Figure 4). A significant difference was only detected after 14 days betw een Ep and the cuprous oxide pain ts with added biocides, $S N$ and Oma. High heterogeneity in biofouling on test panels and a lim ited number of replicates precluded a determination of significant differe nces in the other sam pling periods. Ep paint seemed to exhibit the highest biofouling dry weight after 63 days $(\mathrm{P}=0.065)$. Overall, the total biomass weighted was similar for all paints even after 63 days and averaged $8.38 \mathrm{mg} \mathrm{m}^{-2}$.

Figure 4. Dry weight biom ass in $\mathrm{mg} \mathrm{m}^{-2}$ after 1, 4, 14, 21, 28, 56 and 63 days. Standard deviation is shown with the error bars. Meaning of asterisks is as given in Figure 1.

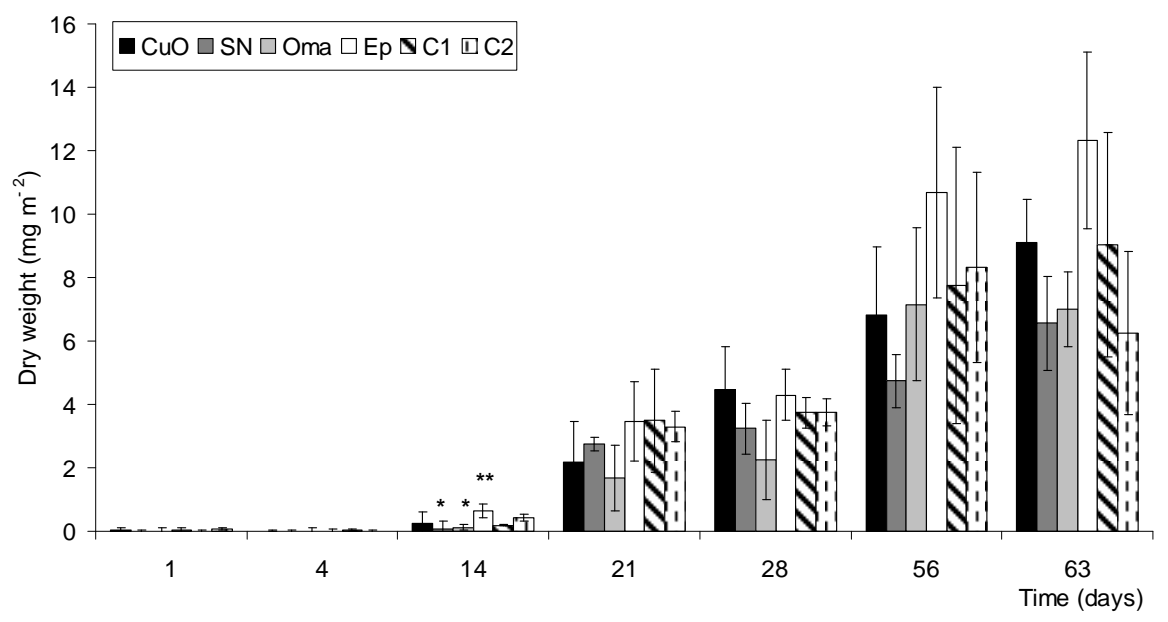

The results of above $\mathrm{m}$ ethods to estim ate biof ouling growth were com pared using two-way ANOVA and differences ( $\mathrm{p} \leq 0.001$ ) were observed in tim e between so me paints (Table 2 ). All four parameters examined can easily discriminate changes with time and between paints but the combining effects of time and paints are best described by chlorophyll a and phytoplankton count. 
Table 2. Two-way ANOVA co mparing the different paints used at the different tim es sampled for all bio logical and ch emical an alyses perform ed. The data were $\log 10$ transformed for cytometry and fluorimetry.

\begin{tabular}{|c|c|c|c|c|}
\hline & \multirow{2}{*}{ Source } & \multicolumn{3}{|c|}{ Field assay } \\
\hline & & MS & F-ratio & $\mathbf{p}$ \\
\hline \multirow[t]{4}{*}{ Bacterial count } & Time 2 & 32.50 & 245.20 & $\leq 0.001$ \\
\hline & Paint 5 & 0.98 & 7.37 & $\leq 0.001$ \\
\hline & Time*Paint 10 & 0.32 & 2.40 & 0.027 \\
\hline & Error 36 & 0.13 & & \\
\hline \multirow[t]{4}{*}{ Phytoplankton count } & Time 2 & 4.03 & 139.20 & $\leq 0.001$ \\
\hline & Paint 5 & 0.47 & 16.21 & $\leq 0.001$ \\
\hline & Time*Paint 10 & 0.57 & 19.68 & $\leq 0.001$ \\
\hline & Error 36 & 0.03 & & \\
\hline \multirow[t]{4}{*}{ Chlorophyll a } & Time 6 & 245.99 & 420.71 & $\leq 0.001$ \\
\hline & Paint 5 & 21.17 & 36.20 & $\leq 0.001$ \\
\hline & Time*Paint 30 & 3.41 & 5.83 & $\leq 0.001$ \\
\hline & Error 84 & 0.59 & & \\
\hline \multirow[t]{4}{*}{ Dry biomass } & Time 6 & 0.01 & 99.54 & $\leq 0.001$ \\
\hline & Paint 5 & 0.00 & 4.88 & 0.001 \\
\hline & Time*Paint 30 & 0.00 & 1.46 & 0.089 \\
\hline & Error 84 & 0.00 & & \\
\hline
\end{tabular}

\subsection{Visual and Microscopic Observations}

Painted panels presented little evidence of biof ouling after three weeks of imm ersion, although a thin slime layer was $\mathrm{p}$ resent on the surface. A few $\mathrm{m}$ acroalgal structures became visible in the fourth week, brown and sticky on $\mathrm{CuO}$ panels, hairy dark green on $\mathrm{C1}, \mathrm{C2}$ and $\mathrm{Ep}$.

Figure 5. Panels as they appeared after 56 days of immersion. A) $\mathrm{CuO}$, B) $\mathrm{SN}, \mathrm{C}) \mathrm{Oma}$, D) Ep, E) C1, F) C2.

A)

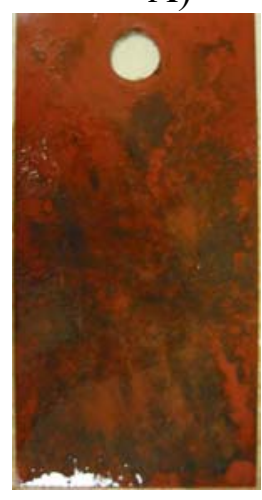

B)

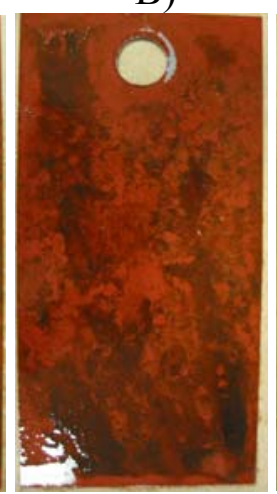

C)

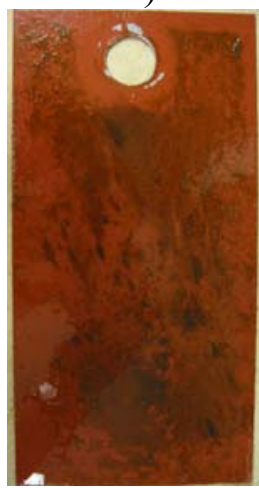

D)

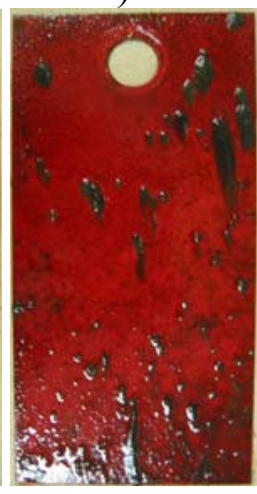

E)

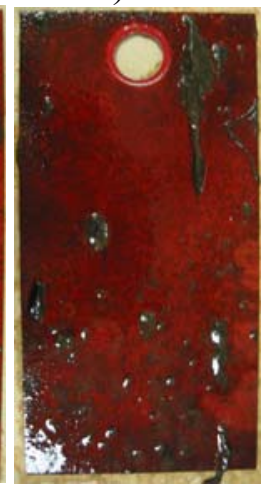

F)

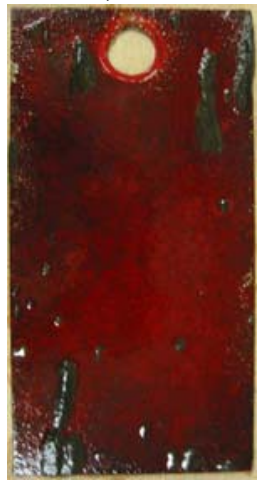


Those macro-structures appeared to be form ed by aggregated colonies of benthic diatom $\mathrm{s}$ of ha rd substrate and hypothesised to be Amphora spp. on $\mathrm{CuO}$ and suggested to be form ed of pennales diatoms (Navicula spp., Nitszchia spp. or Berkeleya spp.) on Ep based paints (not shown). After 56 days, all panels were covered with a layer of $m$ acoralgae (Figure 5). A difference in colonising algae between cuprous oxide based paints (Figures $5 \quad$ A, B and C), form ing a brownish layer, and polyurethane-silicone based paints (Figures $5 \mathrm{D}, \mathrm{E}$ a nd F), with hairy dark green aggregates, was quite evident. Macro-invertebrates such as gastropods, tunicates, and polycheates were not observed on panels even after two months of immersion.

Epifluorescence $\mathrm{m}$ icroscopy perform ed on the or ganic $\mathrm{m}$ aterial harves ted on painted panels revealed the for mation of a filam entous biofilm after 14 days of i mmersion on epoxy-paints, C1, C2 and $E p$ and som e tiny patches on $\mathrm{CuO}$ whereas $\mathrm{Oma}$ and $S N$ panels were not yet colonised by microalgae in accordance with their very low chlorophyll $a$ concentrations. After three weeks, C1, C2 and $E p$ panels were co mpletely covered with an alga 1 film, com posed of vari ous species of benthic diatoms (Figure 6B). Copper painted panels showed well developed bacteria 1 clusters although algae were still $\mathrm{n}$ ot vis ible ( Figure 6 ). After 63 days, all pa nels were in tensely colonized by algae and bacteria with no visual differences between antifouling paints.

Figure 6. Epifluorescence $m$ icroscopy $60 \mathrm{X}$ after 21 immersion days. A) $\quad S N$; B) $C 2$. Bacteria ap pear as green dots and microalgae as red sticks. De bris appears in greenishyellow. White bar: $10 \mu \mathrm{m}$.

A)

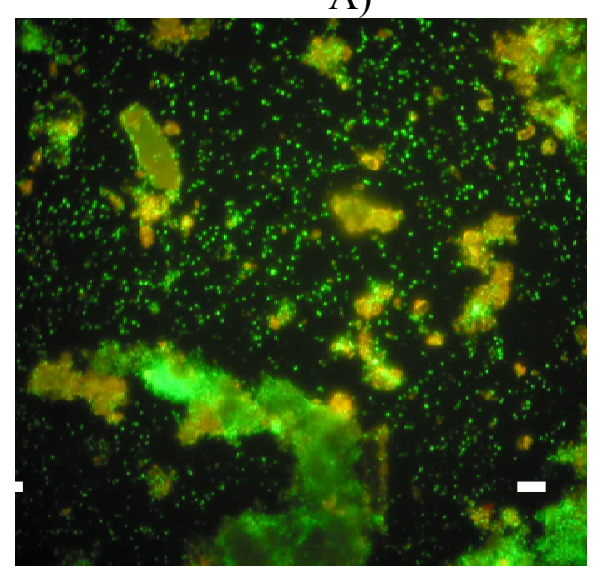

B)

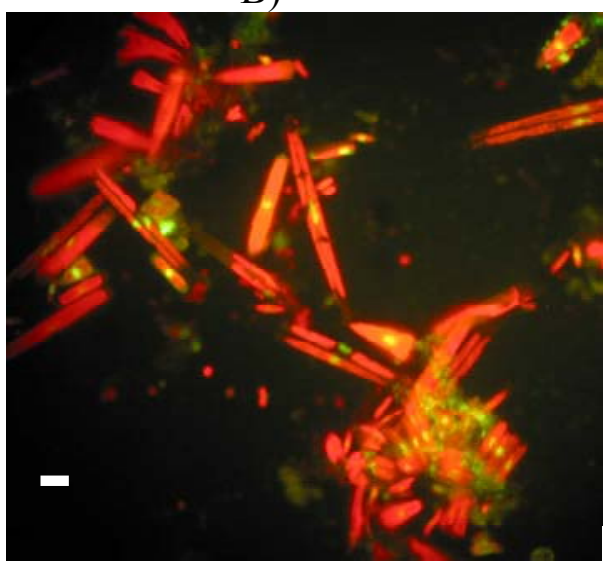

Observations using inverted microscopy on samnles immersed over 63 days confirmed the presence of two different communities involved in the $b$ iofouling process of either cuprous oxide based paints (CuO, SN and Oma) or Easypoxy ${ }^{\mathrm{TM}}$ based paints ( Ep, C1 and C2). Microalgae Amphora spp. Were dominated on cuprous oxide paints (Figure 7A ). On Ep paints a high divers ity of $\mathrm{m}$ icroalgae are visible (F igure 7B). Diatom s such as Navicula spp., Melosira spp., Cocconeis spp., Nitzshcia spp., Fragilaria spp., and Amphora spp. were observed and identified [20]. Specific identification of Navicula directa and Melosira nummuloides was even possible (Figure 7C). 
Figure 7. Inverted microscopy observations, 40X, after 63 days. Nitric and sulphuric acid treatment. A) Oma, B) C2. Without acid treatment: C) Navicula directa, observed on Ep. White bar: $10 \mu \mathrm{m}$.

A)

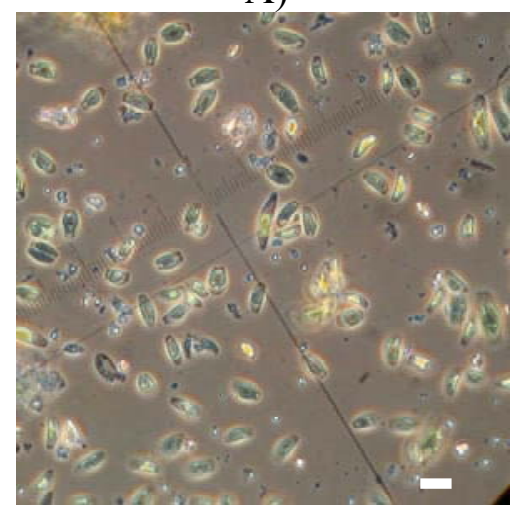

B)

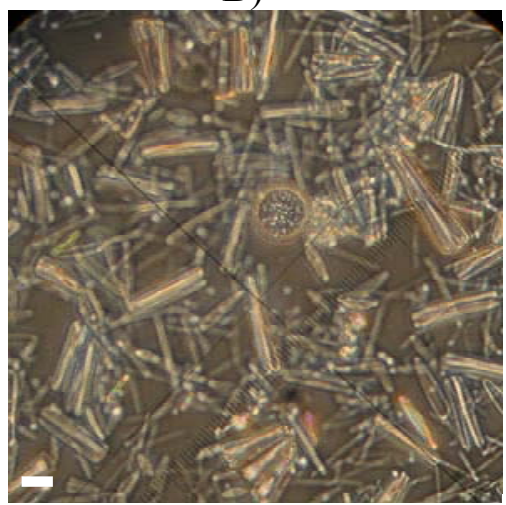

C)

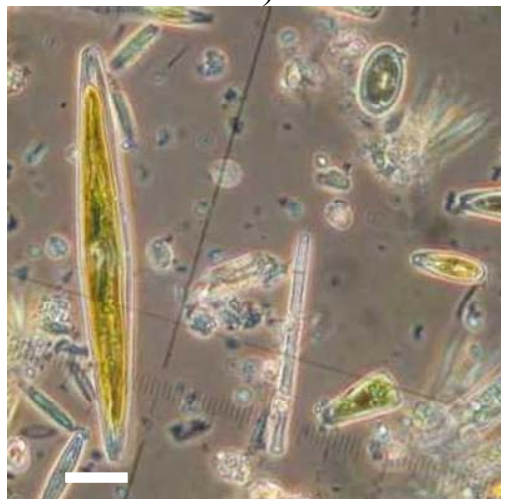

\subsection{Statistical Treatment}

Based on photographic records obtained from epifluorescen ce microscopy, a non-m etric multivariate analy sis $\mathrm{b}$ ased on th e pre sence a nd the a bsence of dif ferent $\mathrm{m}$ icroorganisms was performed. Figure 8 shows the differences and similarities of colonisation between the paints in time.

Figure 8. Structure of the whole assem blage, nMDS ordination on presence-absence data, using Bray-Curtis similarity matrix. Bacteria, bacterial clusters and variation of microalgae morphology observed. Stress $\leq 0.2$ dem onstrates a good gra phical representation of the differences and similarities between paints.

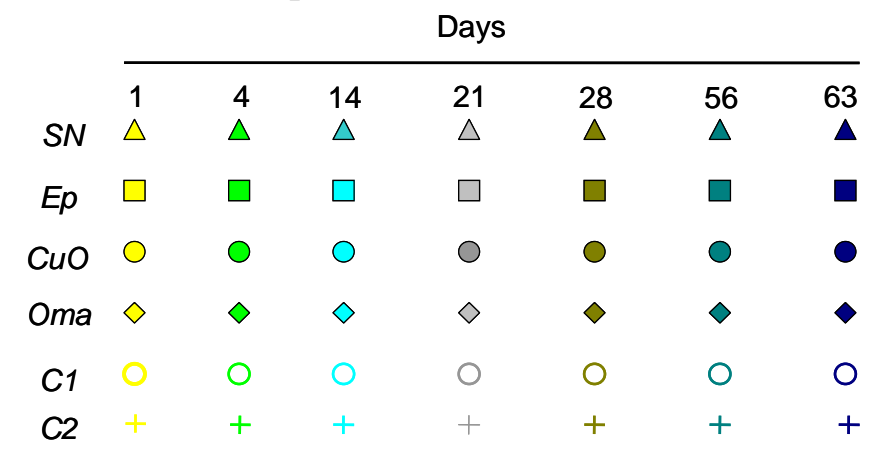

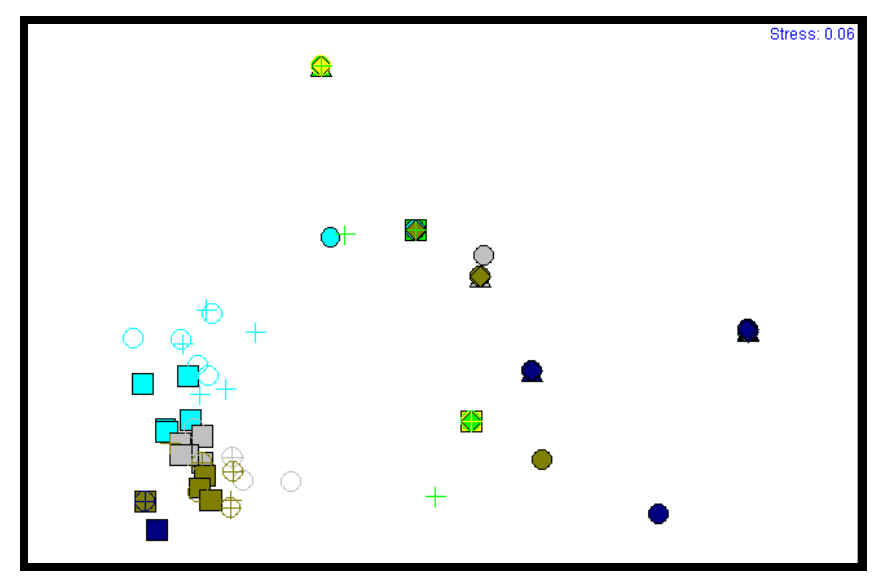


Each paint type is represented by a specific sy mbol and each sam pling day by a different color. Paint types similarly populated by microorganisms have their respective symbols closer to each other. Although some symbols are hidden by others, it is possible to note that Ep, C1 and C2 symbols are clustering in the lower left corner. Those painted pa nels appear to be similarly colonised by organism s in time. The sym bols of $\mathrm{CuO}$, Oma and $S N$ paints a re more spread but still re latively closer to each other. Cuprous oxide based paints are sim ilarly populated but are not related to Easypoxy ${ }^{\mathrm{TM}}$ based paints. Symbols of C2 paint are som etimes superim posed on Oma symbols, but at different tim es showing a different biofouling prog ression on the surface of the pain ts. The stress indication of 0.06 , far under the 0.2 usually admitted, reveals an excellent graphical representation of the differen ces and similarities between the paints in time.

\subsection{Tools to Assess Field Biofouling}

Chlorophyll $a$ content is a good and sim ple tool to estim ate the evol ution of algal biom ass with time, but does not allow the differe ntiation between species involved in the colonisation process of painted panels. Visual observations showed differences of alga genu s colonising cuprous oxide based paints and Easypoxy ${ }^{\mathrm{TM}}$ based paints. Those variations in co mposition of the $\mathrm{m}$ icroalgal communities were confirmed by epifluorescence and inverted m icroscopy. A higher number of species were visible on Ep paints, diatoms such as Navicula spp., Cocconeis spp., Nitzschia spp., Melosira sp., Fragilaria spp., Licmophora spp. and some species of Amphora spp. were observed and id entified. The frequent occurrence on test surfaces of genus Licmophora spp., Navicula spp. and Nitzschia spp., was previously reported [21], but types and num bers of native fouling organism s differ within regions, especially in reg ions where $m$ arked seasonal vari ations in tem perature occur [ 21]. The diatom population on cuprous oxide paints was m ainly composed of Amphora spp. This result was expected and confirms the resistance of this genus of diatom s to coppe $r$ toxicity [22]. Surprisingly, Amphora also appears to be resistant to the organic biocides Oma and SN.

Dry weight analyses include living and non-living organisms and give a good estimation of the total biomass of biofouling with tim e. Paints did not pres ent significantly different values of total biomass on their su rface throug hout the ex periment, except on day 14. Howe ver, a tendency of Ep paint to present higher values of dry weight is noted. Furtherm ore, chitosan paint C2, as well as $S N$ and Oma presented the lowest biomass values after 63 days of immersion. Values obtained were really small and the high heterogeneity between panels and on the sam e panels, especially when m acroalgae started to be abundant, explains the great variability betw een replicates. In spite of these $\mathrm{m}$ ethodological restrictions in the experimental setup, it can be concluded that painted panels immerged nine weeks in northern co ld seawater showed low and sim ilar to tal dry biom ass and algal concentration with or without toxic compounds.

\subsection{Efficiency of Antifouling Components}

The control of the early stage of the biofilm , such as the settling of bacteria, fungi and benthic diatoms, should prevent the settlem ent of subsequent biofoulers such as m acro-algae and larvae [5]. Several studies reported the incorporation of na tural products in antifouling paint form

ulations 
[4-7,23]. However, no attempts have been yet reported to evaluate the potential of solid phase chitosan polymers as antimicrobial additives to a polyurethane-silicon marine paint.

The antimicrobial activity of chitosan has never been directly evaluated in the $\mathrm{m}$ arine environment as a paint additive so the best effective deacylation degree, molecular weight and concentration for an antibacterial action were unknown. Chitosan presenti ng a degree of deacylation of $100 \%$ was chosen for our experim ent as it was previously dem onstrated th at the deacylation level is corr elated to antimicrobial properties [24]. As revealed in num erous studies [8,25], the chitosan molecular w eight has an influence on its solubility and antim icrobial activity. A $450 \mathrm{KDa}$ easily produced polymer was chosen for the evaluation of the an tifouling potential of chitosan. The solubility of chitosan in siliconpolyurethane paint is unknown and field tests are essential to estimate the real behaviour of the coating once imm ersed as it could be inf luenced by various environm ental changes. Chitosan C1 $5 \%$ concentrated) presented an interesting antibacterial action after $24 \mathrm{~h}$, but $C 2$ (20\% concentrated) seems to present a $\mathrm{m}$ ore prom ising antim icrobial action. W ith concentrations below $2 \% \mathrm{~W} \mathrm{v} \quad{ }^{-1} \mathrm{c}$ hitosan presents antibacterial activity against som e gene ra of $\mathrm{m}$ icroorganisms involved in the biofouling process such as Pseudomonas, Vibrio and Bacillus [8,24,26]. Our own tests using solid-phase chitosan demonstrated that $5 \% \mathrm{~W} \mathrm{v}^{-1}$ presented some antibacterial ch aracteristics, but effects of the $20 \% \mathrm{w} \mathrm{v}^{-1}$ composition seems to last longer. $\mathrm{C}$ hitosan polymer has also been reported to control the growth of algae [27], but its action was neve $r$ dire ctly tested in th e $m$ arine en vironment as an anti-f ouling additive. Within the present expe riment the anti- algal ac tivity of the polym er of chitosan was not demonstrated and painted panels presented an alga $1 \mathrm{~g}$ rowth clos ely s imilar to pa nels pa inted with control Ep. No attempt was made to optimize the concentration of chitosan in the present work.

A $\mathrm{m}$ uch bette $\mathrm{r}$ an tibacterial activ ity of the additive Omadine ${ }^{\mathrm{TM}}$ over all oth er pain ts wa $\mathrm{s}$ demonstrated. Results are in agreement with the technical bulletin published by Arch Che micals, Inc. [28], where Copper Omadine ${ }^{\mathrm{TM}}$ is reported to exhibit pronounced growth inhibiting activity against a broad spectrum of both Gram negative and Gram positive bacteria, as well as fungi and yeast and to outperform all paints containing only cuprous oxide. All cuprous oxide based pa ints demonstrated an anti-algal action, with $S N$ and Oma additives being more efficient than any other paint for the first four weeks. Molino et al. [29] reported recen tly the role p layed by bacterial comm unity during the early stages of colonisation on immerged surfaces and compared a number of antifouling paints in field tests held in tem perate and tropical waters. They observe $\mathrm{d}$ a rapid m odification of the coating surfaces (as fast as four days) and a co rrelation with bo th loca tion and s eason. Diatom s dom inating in the microfouling biofilm are known to be highly resistan $t$ to copper antifouling pa ints [30], but not to organic biocides added to inhibit the growth of resistant algae such as Enteromorpha spp., Ectocarpus spp., and Achnanthes spp. [31]. Moreover, Sea-Nine ${ }^{\circledR} 211$ is claimed to have a broad spectrum activity against diatom s, algae, barnacle s, tubeworm s, hydroids, bryozoans and tunicates [32]. However, all paints, with or without additives, presented on their su rfaces similar concentrations of chlorophyll $a$ pigment after two $\mathrm{m}$ onths, suggesting the absence of a real long-term anti- algal action of organic biocides paints in cold e stuarine seawaters. Results may have been different in a d ynamic test where strong currents may have removed a part of the biofilm. 


\section{Experimental Section}

\subsection{Settlement Device}

Steel panels of $10 \mathrm{~cm}$ x $20 \mathrm{~cm}$ with a $2 \mathrm{~cm}$ diameter centered hole at $1 \mathrm{~cm}$ from the top were used. Abrasive blasting, cleaning and dryi ng of the panels were perform ed before the ir pre-treatment with primer coating (Interprotect 2000E $®$ from Interlux, Ltd). Panels were spra yed on both sides with marine paints then vertically and random ly fram ed in triplicate on ABS (Acrylonitrile Butadiene Styrene plastic) tubes from the exposure racks following a protocol proposed by the American Society for Testing Materials [12]. Each ra ck, supporting 24 panels, was attach ed to the floating raft of the Rimouski harbour $\left(48^{\circ} 28^{\prime} \mathrm{N} 68^{\circ} 30^{\prime} \mathrm{W}\right.$ ) along the St. Lawrence Estuary with a south west sun exposition and immersed at $50 \mathrm{~cm}$ below the water level as suggested by Stupak et al. [13].

\subsection{Weather and Seawater Conditions}

The water temperature at Rimouski pier fell from $13.7^{\circ} \mathrm{C}$ to $7.1^{\circ} \mathrm{C}$ during the experiment period and a solar radiation decrease from $47.5 \mathrm{E} \mathrm{m}^{-2}$ day $^{-1}$ to $17.5 \mathrm{E} \mathrm{m}^{-2}$ day $^{-1}$ was observ ed as the exp eriment was conducted through summer and autumn conditions from August $12^{\text {th }}$ to October $14^{\text {th }} 2005$. A total of $243 \mathrm{~mm}$ of rain were $\mathrm{m}$ easured during the 27 raining days recorded over the two $\mathrm{m}$ onths of experimentation. Average seawater salinity was $23 \mathrm{ppm}$ and dissolved oxygen stayed near saturation at $9.1 \mathrm{~m} \mathrm{~g} \mathrm{O}{ }_{2} \mathrm{~L}^{-1}$. Nutrient concentrations (phospha tes $=0.94 \mu \mathrm{M}$; nitrates $=6.6 \mu \mathrm{M}$ and silicates $=18.3 \mu \mathrm{M}$ ) were typical to estuarine cond itions and highly favourable to algal productivity . Suspended particulate matter averaged $3.1 \mathrm{mg} \mathrm{L}^{-1}$ during calm conditions, but reached $90 \mathrm{mg} \mathrm{L}^{-1}$ under stormy conditions. The $\mathrm{m}$ ean $\mathrm{pH}$ va lue was 7.96 dur ing dry days and dropped to 6.86 in rainy days. Currents with the Rimouski habour were subjected to tidal pulses and rarely exceeded $3 \mathrm{~cm} \mathrm{sec}^{-1}$.

\subsection{Commercial and Chitosan Paints}

Chitosan was prepared from waste Pandalus borealis shrimp shells by successive deproteinisation, demineralisation and deacylation of chitin. Three comm ercially available paints, cupr ous oxide paint Bottomkote ${ }^{\circledR} X X X$ (Interlux, Ltd.), liquid Sea-Nine ${ }^{\circledR} 211$ cuprous oxide paint additive (Rohm \& Haas Inc., Philadelphia, US.), Copper Omadine ${ }^{\mathrm{TM}}$ powder additive for cuprous oxide paint (Arch Chem icals Inc., Norwalk, US), and two granular chitosan a dded paints were co mpared for their an tifouling properties (Table 1). Easypoxy ${ }^{\mathrm{TM}}$ polyurethane paint (Pettit Marine Paints Division of Kop-Coat, Inc., Rockaway, US.), a $\mathrm{m}$ arine paint without antifouli $\mathrm{ng}$ biocide, was used as a referential non-toxic surface. All paints were red to minimise possible color bias on biofouling process.

\subsection{Sampling Procedure}

Seven racks were used over a two-month period and sampled after 1, 4, 14, 21, 28, 56, and 63 days. An exposure rack, containing 24 suspended panels, was re moved and inspected at each sampling time. Organic material firmly atta ched to panels was scrapped of $f$ with a ster ile razor blade for di fferent 
analyses [14]. Material collected from a $60 \mathrm{~cm}^{2}$ surface was washed with sterile fresh water to remove sea salt and freeze-dried for the $\mathrm{d}$ etermination of dry weig ht expressed in $\mathrm{m} \mathrm{g} \mathrm{m}^{-2}$. A second $20 \mathrm{~cm}^{2}$ surface was scraped off and the org anic material removed with sterile s tandard seawater (SSW : $33 \mathrm{~g}$ $\left.\mathrm{NaCl} \mathrm{L}{ }^{-1}\right)$. The resultin $\mathrm{g}$ sam ple was preserv ed in $2 \%$ form alin at $-80^{\circ} \mathrm{C}$ and a nalysed by flow cytometry for bacterial count, epif luorescence $\mathrm{m}$ icroscopy for bacterial and algal observation, and inverted microscopy for algae identif ication. Organic material collected from another $20 \mathrm{c} \mathrm{m}^{2}$ surface was preserved at $-80^{\circ} \mathrm{C}$ and analysed in spectrofluorim etry for the determination of the chlorophyll $a$ content.

\subsection{Direct Photographic and Microscopic Observations}

Digital photographic records were obtained and us ed to compare biofouli ng progression. Thawed samples preserved in formalin $(500 \mu \mathrm{L})$ were stained for $15 \mathrm{~min}$ at $20^{\circ} \mathrm{C}$ in the dark with $0.2 \%$ SYBR green I (Molecular Probes, Inc.). After staining, bacteria and algae from the biofilm were trapped onto $0.2 \mu \mathrm{m}$ black polycarbonate $\mathrm{m}$ embranes (Osmonics, Inc.) and observed with an Olym pus BX40 microscope. A $530 \mathrm{~nm}$ FITC filter was us ed fo $\mathrm{r}$ epifluorescence $\mathrm{m}$ icroscopy observation and photographic records. F rom the sam e thawed sam ple, a $100 \mu \mathrm{L}$ aliquot was observed in inverted microscopy at $40 \mathrm{X}$ according to the procedure desc ribed by Lund [15] for algae identification and numerical microphotographs were ta ken. A nitric and sulphuric acid treatment was applied to $1 \mathrm{~m} \mathrm{~L}$ fixed samples for identification of diatoms using inverted microscopy.

\subsection{Flow Cytometry}

Samples preserved at $-80^{\circ} \mathrm{C}$ in $2 \%$ form alin were thawed an $\mathrm{d} 1 \mathrm{~m} \mathrm{~L}$ was used for flow cytom etry analysis (FACSort, Becton Dickinson ${ }^{\mathrm{TM}}$ ) to reveal th e presence of bacteria a nd algae in the samples. Bacterial population samples were stained with the high-affinity nucleic acid SYBR green I according to procedure previously described [16] and natu ral fluorescence of the phytoplankton population was detected. An internal standard $\mathrm{m}$ ixture, consisting of $2 \mu \mathrm{m}$ diam eter beads (Polys ciences, Inc.) was added to each sam ple. Analyses were pe rformed on Ce 1lQuest software version 1.0 @ (Be cton Dickinson Immunocytometry Systems). An isolated bacterial population, formed by cells smaller than $2 \mu \mathrm{m}$, was detected and $\mathrm{m}$ easured. Bacterial counts per $\mathrm{cm}^{2}$ as a reference of $\mathrm{s}$ urface colonisation were determined.

\subsection{Chlorophyll A}

Samples preserved at $-80^{\circ} \mathrm{C}$ were thawed and $1 \mathrm{~mL}$ was analysed in fluorim etry following Trees $e t$ al. [17]. Briefly, samples were added in a $90 \%$ acetone solution, quickly sonicated and left in dark $24 \mathrm{~h}$ at $4^{\circ} \mathrm{C}$ for pigm ent extraction. Analysis was perf ormed with a Turner Designs Fluorom eter, and concentrations expresse $\mathrm{d}$ in ng of chlorophyll $a$ per $\mathrm{cm}^{2}$ were calculated $\mathrm{u}$ sing the Stricklan $\mathrm{d}$ and Parsons method [18]. 


\subsection{Statistical Tests}

Differences in the $\mathrm{m}$ ean values of biofouling grow th in time between e ach paint were de termined using a two-way analysis of va riance (ANOVA). Flow cytom etry an d fluorim etry analyses results were $\log 10$ transformed to obtain a norm al distribution of frequencies. The location of all racks at the pier raft was randomly distributed and was considered to have no effects on the results. The analysis of variance was followed by a Tukey post-hoc test. Probabilities lower than or equal to 0.05 were considered significant. Using the photographic records obtained from microscopic epifluorescence, multivariate analys es were performed. Differences in the structure of whole as semblages among the six paints w ere identified by non-metric $\mathrm{m}$ ulti-dimensional scaling (nM DS) ordination on pres enceabsence data, using the Bray-Cur tis sim ilarity m easure [19]. The pres ence or abs ence of bacteria, bacterial clusters and various morphologies of microalgae were specifically observed (Table 2).

\section{Conclusions}

Methods adapted here to evaluate the biofouling growth in tim e we re useful to understand how colonisation on painted surfaces $\mathrm{p}$ rogresses. Anal yses $\mathrm{p}$ erformed on bacterial and phytoplankton populations provided new details on the early stages of biofouling in the St. Lawrence Estuary, rarely investigated before. Microscopi c observations provided som e sp ecific indications on the algal community composition, information improving our knowledge of the fouling diatom s in the Estuary. Our results question the interest of using antifouling paints and additives organic biocides on ship hulls navigating the St. Lawrence Estuary as the fouling is slow to take $p$ lace and all $p$ aints were equally inefficient after two months. This suggests that expensive and toxic co pper paints need not been used on immersed structures in St. Lawrence Estuary as they are useless towards the slow biofouling taking place over $\mathrm{s}$ ummer m onths. The dis covery of a lowe $r$ bacterial adhe rence for solid phase chitosan added to a commercial marine paint without any pesticide antifouling compound is encouraging for the development of a green chemistry approach to harm ful effects of biofouling. This natural polymer has excellent properties such as non-toxicity, non-allergenicity, biocompatibility and biodegradability [27]. However, in com parison to cuprous oxide based pa ints with and withou t additives, chitosan was not efficient against $\mathrm{m}$ icroalgae in the early stage of the biofouling. A much better understanding of chitosan mechanism of action against marine bacteria is needed. The use of chitosan as an antibacterial additive combined to an environmentally safe anti-algal additive justifies further efforts in formulating chitosan-base anti-fouling additive s. Optim al concen tration and granula $\mathrm{r}$ size of chitosan shou ld be determined in a further work. The work should also be extended to the sett lement of invertebrate larvae already well described in the St. Lawrence Estuary.

\section{Acknowledgments}

This research has been suppor ted by Marinard Biotech Inc ., the Natural Sciences and Engineering Research C ouncil of C anada - Discovery Program , and the Canada R esearch Chair in Molecular Ecotoxicology (E.P.). Anti-fouling pa int additives have been graciously provided for test experiments by Arch Chemicals, Inc. (Norwalk, US), and Rohm \& Haas, Inc. (Philadelphia, US). 


\section{References}

1. Yebra, D.M.; Kiil, S.; Da m-Johansen, K. Antifouling tech nology-past present an d future steps towards efficient and en vironmentally friendly antifouling coatings. Prog. Org. Coat. 2004, 50, 75-104.

2. Evans, S.M.; Leksono, T.; McKinnell P.D. Tribultytin pollution: a diminishing problem following legislation limiting the use of TBT-based anti-fouling paints. Mar. Pollut. Bull. 1995, 30, 14-21.

3. Konstantinou, I.K.; Albanis, T.A. Worldwide occurence and effects of antifouling paint booster biocides in the aquatic environment: a review. Environ. Int. 2004, 30, 235-248.

4. Armstrong, E.; Boyd, K.G.; Bur gess, J.G. Prev ention of $\mathrm{m}$ arine biofouling using natural compounds from marine organisms. Biotechnol. Annu. Rev. 2000, 6, 221-241.

5. Burgess, J.G.; Boyd, K.G.; Ar mstrong, E.; Jiang, Z.; Yan, L.; Berggren, M.; May, U.; Pisacane, T.; Granm o, A.; Ada ms, D.R. The developm ent of a $\mathrm{m}$ arine natural product-based antifouling paint. Biofouling 2003, 19, 197-205.

6. Clare, A.S. Marine natural products antifoulants:status and potential. Biofouling 1996, 9, 211-229.

7. Tsoukatou, M.; Maréchal, J.P., He 1lio, C.; Novakovic, I.; T ufegdzic, S.; Sladié, D.; Gasié, M.J .; Clare, A.S.; Vagias, C.; Roussis, V. Evaluation of the activity of the sponge $m$ etabolites Avarol and Avarone and their synthetic derivatives against fouling micro- and $\mathrm{m}$ acroorganisms. Molecules 2007, 12, 1023-1034.

8. No, H.K.; Park, N.Y.; Lee, S.H.; Meyers, S.P. Antibacte rial ac tivity of chitosans and chitosa $\mathrm{n}$ oligomers with different molecular weights. Int. J. Food Microbiol. 2002, 74, 65-72.

9. Roller, S.; Covill, N. The antif ungal properties of chitosan in labo ratory media and apple ju ice. Int. J. Food Microbiol. 1999, 47, 67-77.

10. Wu, R.S.S.; La m, P.K.S.; Zhou, B.S. A settlem ent inhibition assay with cyprid larvae of the barnacle Balanus amphritrite. Chemosphere 1997, 35, 1867-1874.

11. Iken, K.; Greer, S.P.; Am sler, C.D.; McClintoc k, J.B. A new antifouling bioassay m onitoring brown algal spore swimming behaviour in the presence of echinoderm extracts. Biofouling 2003, 19, 327-334.

12. ASTM. Standard test $m$ ethod for testing an tifouling panels in shallow submergence. In Annual book of ASTM Standards. Am erican Society for Testing Materials: West Conshohocken, PA, USA, 1998; Designation D 3623-78a.

13. Stupak, M.E.; Garcia, M.T.; Pérez, M.C. Non-t oxic alternative compounds for marine antifouling paints. Int. Biodeter. Biodeg. 2003, 52, 49-52.

14. Araya, R.; Tani, K.; T akagi, T,; Ya maguchi, N.; Nasu. M. Bacterial activity and community composition in stream water and biofilm from an urban river dete rmined by fluorescent in situ hybridization and DGGE analysis. FEMS Microbiol. Ecol. 2003, 43, 111-119.

15. Lund, J.W .G.; Kipling C.; Le Cren, E.D. The i nverted m icroscope m ethod of estim ating algal numbers and the statistical basis of estimations by counting. Hydrobiologia 1958, 11, 143-170.

16. Lebaron, P.; Servais, P.; Agogue, H.; Courties, C.; Joux, F. Does the high nucleic acid content of individual bacterial cells allow us to discriminate between active cells and inactive cells in aquatic systems? Appl. Environ. Microbiol. 2001, 67, 1775-1782. 
17. Trees, C.C.; Bidigare, R.R.; Karl, D.M.; Van Heukelem , L.; Dore, J. Fluorimetric chlorophyll a: sampling laboratory methods and data analysis protocols. In For satellite ocean color sensor validation NASA Technological Memo; NASA: Washington, DC, USA, 2000.

18. Strickland, J.D.H.; Parsons, T.R. A practical handbook of seawater analysis, $2^{\text {nd }}$ ed.; Fisheries Research Board of Canada: Ottawa, ON, Canada, 1972; p. 310.

19. Clarke, K.R. Non-param etric multivariate an alyses of changes in community structure. Aust. J. Ecol. 1993, 18, 117-143.

20. Cardinal, A.; Poulin, M.; Bérard-Thérriault, L. Les diatom ées benthiques de substrats durs des eaux m arines et saum âtres du Q uébec. 5. Naviculales Naviculaceae (les gen res Navicula, Donkinia, Gyrosigma et Pleurosigma). Natur. Can. Ann. Rev. Eco. System. 1986, 113, 167-190.

21. WHOI (W oods Hole O ceanographic In stitution). Marine fouling and its prevention; Naval Institute: Annapolis, MA, USA, 1952; Volume 580, p. 388.

22. Brown, L.N.; Robinson, M.G.; Hall, B.D. M echanisms for copper tolerance in Am phora coffeaeformis-internal and external binding. Mar. Biol. 1988, 97, 581-586.

23. Fusetani, N. Biofouling and antifouling. Nat. Prod. Rep. 2004, 21, 94-104.

24. Jumaa, M.; Furkert, F.H.; Muller, B.W. A new lipid emulsion formulation with high antimicrobial efficacy using chitosan. Eur. J. Pharm. Biopharm. 2002, 53, 115-123.

25. Tokura, S.; Ueno, K.; Miyazak i, S.; Nishi, N. Mo lecular weight dependent antim icrobial activity by chitosan. Macromol. Symp. 1997, 120, 1-9.

26. Sekiguchi, S.; Miura, Y.; Kaneko, H.; Nishimura ， S.L.; Nishi, N.; Iw ase, M.; Tokura, S. Molecular weight dependency of antim icrobial activity by chitos an oligom ers. In Food hydrocolloids: Structures Properties and Functions; Nishinari, K., Doi, E., Eds.; Plenum Press: New York, NY, USA, 1994; pp. 71-76.

27. Ravi Kum ar, M.N.V. A review of chitin and chitosan applications. React. Func. Polym. 2000, 46, 1-27.

28. Copper Omadine bactericide-fungicide for antifouling marine paint. Technical product information, marine antifouling paints. Technical Bulletin AB-9: Vers1 Eff 4/99. Arch Chemicals Inc.: Norwalk, CT, USA, 1999; p. 5.

29. Molino, P.J.; Childs, S.; Eason Hubbard, M.R. ; Carey, J.M.; Burgm an, M.A.; Wetherbee, R. Development of the prim ary bacterial $\mathrm{m}$ icrofouling layer on antifouli $\mathrm{ng}$ and fouling release coatings in tem perate and tropical environments in Eastern Australia. Biofouling 2009, 25, 149162.

30. Anderson, C.; Atlar, M.; Callow, M.; Candries, M.; Milne, A.; Townsin, R.L. The development of foul-release coatings for seagoing vessels. J. Mar. Des. Oper. 2003, B4, 11-23.

31. Voulvoulis, N.; Scrim shaw, M.D.; Lester, J. N. Review: Alternative antifouling biocides. Appl. Organomet. Chem. 1999, 13, 135-143.

32. Material safety data sheet for Sea-Nine 211 marine anti-fouling agent. Key: 866324-3 1-7. Rohm \& Haas Company Inc.: Philadelphia, PA, USA, 2002.

(C) 2009 by the authors; licensee Mol ecular Diversity Preservation Inte rnational, Basel, Switzerland. This article is an op en-access article distributed unde $r$ th e term $s$ and condition $s$ of the Creativ e Commons Attribution license (http://creativecommons.org/licenses/by/3.0/). 